\title{
Mediating Aspirant Religious-Sexual Futures: In God's Hands?
}

This paper explores the construction of vocational and familial futures, in times of 'aspiring', 'post-welfare,' or 'crisis' youth transitions, as mediated by sexual-religious identification. By considering the intersectional relations of both sexuality and religion in constructing young people's aspirations, the paper highlights pragmatic and caring orientations, including a 'calling' to religion as a site of present-future vocational and familial investment. I challenge the separation of religion and sexuality in youth transitions, and in notions of the 'times we're in' as compelling certain kinds of future-orientated aspirant (and secular) selves. Overall, the article hopes to contribute to theorising the intersection sexuality and religion in further understanding the subversive - and conservative - potential of religious-sexual values and futures. Such orientations interface with aspects of 'getting by' and 'getting on' and at once re-inscribe and stretch normative vocational and familial choices.

\section{Introduction: Youth Futures, Queer Precarity and Religions (Un) Certainty}

Generally, both religion and sexuality are under-investigated as influencing young peoples' vocational and familial futures. In terms of sexuality, young people find themselves awkwardly navigating a youth-at-risk discourse, as well as a youth-assexually-liberated-and-free discourse (Yip and Page, 2013). Existing research has often been premised on concerns around the risks faced by lesbian and gay youth that make transitions to adulthood difficult (e.g. discrimination, homophobia, drug use, homelessness, risky sexual behaviour, social isolation, suicide) (Rivers and D'Augelli, 2001; Taylor, 2011). Overly psychological and 'risk' based approaches arguably deny the agency of young people in constructing their own identities, and can impose a homogenous image of lesbian and gay youth as 'at risk' (Rasmussen, 2006; Taylor and Snowdon, 2014a; Taylor et al., 2014).

Such ideas of risk arguably pervade the category of youth more generally, witnessed in recent policy and political discourses (Allen and Taylor, 2013). The discourse of 'aspiration' as a self-motivational tool that can propel young people into secure employment positions, effectively managing social risk despite increasing employment precarity and the financialisation of higher education (Falconer and Taylor, 2016), is increasingly promoted as policy and cultural cure for social-ills. Indeed being 'someone' who aspires in particular ways is becoming an imperative cutting across political discourse and tropes of aspiration and social mobility in British society (Evans, 2010; Friedman, 2015). This becoming 'someone' as a selfactualised and entitled subject is also apparent within celebrations of the 'world we've won' as lesbian, gay, bisexual, transgender (LGBT) groups realise sexual citizenship in the realms of family and working lives (Weeks, 2006; McDermott, 2011). In 'arriving' in places of sexual citizenship, young people are often seen as the beneficiaries of previous generations' struggles but are simultaneously invisiblised as 'not yet' fully in the worlds of family and employment.

This paper is attentive to specific categories, namely youth, religion and sexuality, whilst recognising the ways these are always intertwined with other social positions in the creation of vocational and familial futures (Armstrong, 2010; Weeks et al., 2001). Such categories are themselves moveable and contested with the terms 'youth', 
'religion' and 'sexuality' stretched to mean different things, across time and place. The consideration of both sexuality and religion in constructing young people's futures is necessarily complicated, a complexity often announced by the term 'intersectionality'. Various authors have debated the problems of 'adding in' categories of social difference and inequality, problematizing the 'mantra' like recital of 'race, class and gender' as the categories that matter in shaping futures (Taylor et al., 2010). Considering such stretches, I hope to link different disciplinary literatures and acknowledge the possibility of productive connections between these, rather than overly-burdening the reader - or the author - with 'too many' categories. For those occupying and thinking through these categories, this work of weaving together, rather than simply 'adding in', multiple strands is necessary. Such efforts also work against the disciplinary divisions in the fields of 'youth studies', 'sexuality studies', and 'religious studies'.

Within youth studies, young people are often positioned as inhabiting a transitional stage, 'neither the first nor the last', in the life course, existing 'in transition' and 'as transition' (Jones, 2009: 84). Such impermanence and immanence is often seen as unbound by tradition or 'what was', and opening up to a future unknown. Within sexuality studies, work on lesbian, gay, bisexual, transgender, queer (LGBT) populations often disregards religious aspects of LGBT lives or refers to religious associations as negative, harmful or superficial (Gross and Yip, 2010; Kubicek et al., 2009; Yip, 1997a). Yet various religious institutions and stances have articulated enormously complicated and contrary perspectives (Hunt 2009; Taylor and Snowdon, 2014), perhaps contributing to confusions and uncertainties around queer religious youth. Locating young people in specific, changing times means being attentive to how they construct their personal and social identities, and future possibilities.

Young people dwell on the 'times we're in' and what the future might hold for them, where much commentary points to increased risk, individualisation, detraditionalisation and subjectivisation (e.g. Heaphy 2007, Heelas and Woodhead 2005 Yip and Page, 2010). Rather than viewing religion as another matter of individualized choice and lifestyle, which citizens are increasingly opting out of, Modood (2015) argues against secularism and for a positive role for religion in contemporary society, and for thinking about religion as a public, not just a private good. Indeed, in 'postwelfare' times of economic crisis, austerity and cutbacks, religious bodies and individuals have been asked to 'stand-in' and care for congregations and communities, arguably extending their collective and social capacities as key organisers of public good. Religion has also been considered as a site of social investment and return, as a buffer against isolation and risk and as a space for capital accumulation of both a social and material nature (Mellor, 2010). The long-standing reality of religious spaces that 'provide' and 'care' for communities and congregants is arguably heightened in contemporary post-welfare times. This practice may increase the visibility and desirability of religious orientations, specifically for young people, as counter-normative, even activist and 'anti-capitalist'.

A sense of queer precarity - of not necessarily having access to the 'right kind' of normative future, as well as a sense of religious (un)certainty - of religious commitment potentially in doubt, mediated young people's becoming otherwise. This article hopes to contribute to theorising the intersection of sexuality and religion, and to further understanding of the subversive and conservative potential of religious- 
sexual values and futures. There is scope to consider collective orientations and religious vocations, alongside a turn to individualization and de-traditionalisation, where a 'calling' to religion as a site of present-future vocational investment may weave in alternative and conservative possibilities for young lives. This article explores the construction of vocational and familial futures, in times of 'aspiring', 'post-welfare', or 'crisis' youth transitions, as mediated by sexual-religious identification. It asks, how and in what ways are respondents' religious-sexual futures placed 'In God's hands' and what choices, precarity, and (un)certainty are invested in and how are they balanced. It draws upon a UK-based ESRC funded research project Making Space for Queer Identifying Religious Youth (2015) which considers LGBT youths' constructions and experiences of religious and sexual fields, as typically separated and oppositional in everyday cultural imaginaries and socio-legal policy framings.

In this research, many young people articulated committed caring orientations, which aligned with future caring vocations. While valuing such destinations, they were often aware that caring professions are heavily gendered and not typically well remunerated (Taylor and Snowdon, 2014). Respondents actively voiced 'anti-capitalist' sentiments but these ambivalently interfaced with aspirant and pragmatic orientations, as conveyed in the sentiment of not being able to 'live by bread alone'. The respondents in this study do not neatly 'buy into' the current 'rhetoric of aspiration and concurrent framing of upward mobility as an unequivocal good' (Allen, 2013:761), rather their religious-sexual subjectivity orientates towards 'caring', 'collective' values (Skeggs and Loveday, 2012). Participants did not understand career progression and social mobility as unequivocally beneficial, and instead there was frequent scepticism and an active stance against individualist orientations. The religious and sexual subjectivity of the respondents produces alternative notions of success and status.

Religious cares can form part of an alternative and conservative value system, with many respondents expressing a desire to work in inclusive and/or traditional Churches ${ }^{\mathrm{i}}$, expressing this as a vocational 'calling'. Young LGBT individuals who are simultaneously negotiating their religious-sexual subjectivities, often figure these formations into their consideration of future selves, extending beyond but also including and potentially re-shaping the realm of employment and family (Weeks et al, 2000). This re-shaping raises questions about what kinds of subjectivities or 'selves' can be, and are, being produced, and challenges the story of youth 'in crisis' or properly aspirant. In fact both queer and religious orientations may act to operationalize a more caring, collective subjectivity to be materialised through certain occupational choices, and indicative of alternative values and futures.

This paper explores the construction of vocational and familial futures as mediated by sexual-religious identification. It aims to accord weight and significance to an intersectional orientation to these categories and complexities, navigating respondents' own mediation of futures. It highlights pragmatic and caring orientations, including a 'calling' to religion as a site of present-future vocational investment. Intersectional relations of both sexuality and religion actively construct young people's aspirations, towards pragmatic and caring orientations, as away from a self-accumulating subject able to 'get on' and 'get ahead'. Here, I challenge the separation of religion and sexuality, particularly in terms of youth 'transitions' and in notions of the 'times we're in' as compelling certain kinds of future-orientated 
aspirant selves (Allen and Taylor, 2014). Religion can be queered as an inclusive practice and one which young LGBT people are not automatically or wholly excluded from in living through their future-orientations and pragmatic aspirations in 'gettingby' (Taylor 2015, Modood 2015). Young people may actively conceive of alternatives to dominant exchange value relationships and structures of chrono-normative temporalities, as upwardly mobile, aspirant and becoming (Edelman, 2004; Halberstam, 2005; Love, 2007). Here, both a sense of queer precarity - of not necessarily having access to the 'right kind' of normative futures - as well as a sense of religious (un)certainty - of religious commitment potentially in doubt - mediated young people's becoming otherwise. Before moving to the substantive themes of religious-sexual futures in precarious times, and the pragmatic, alternative and conservative responses to these through imagined and intersecting 'work', 'church' and 'family' futures, I will explain the project's methodology.

The project sought to commit to the research application of 'intersectionality' in terms of religious-sexual youth, informed by theoretical debates and methodological complications of a 'hard to reach' group (see Taylor, 2015). This potential of intersectionality, as animating how social divisions inform one another, and what specific advantages and disadvantages emerge, means resisting a neat evidencing of what intersectionality 'is' as a final conclusion. Here I attempt to highlight and empirically evidence often complicated, rather than neat, list-like or complete, intersections of religious-sexual youth identity and experiences in familial-vocational realms.

\section{Project Methods: Making Space for Queer-Identifying Religious Youth}

This article is based upon a broader ESRC funded project titled Making Space for Queer-Identifying Religious Youth (Taylor, 2015), which explores youth cultures, queer community and religiosity. Its purpose is the probe at the distinction made between religion and sexuality, specifically examining queer Christian youth ${ }^{\mathrm{ii}}$, their experiences, perspectives and perceptions. Whilst non-heterosexuality is still often associated with secularism, and some sources cast religion as negative or harmful to the realisation of LGBT identity (or 'coming out'), this study works against this dominant discourse by exploring the experiences of young LGBT people's connections with Christianity.

Over the course of the fieldwork for the project (2011-2013) 38 respondents were recruited across 3 UK sites: Newcastle, Manchester, and London. The project adopted a mixed-method research design, consisting of individual face-to-face interviews, diaries, and a mapping exercise. The interviews lasted between one and two hours and were conducted between October 2011 and November 2012 and were conducted in participants' homes, a church, a cathedral, a youth centre, universities, cafes, and through one Skype interview. Interviews were semi-structured, exploring family, education, work, leisure, relationships and identity, religion, and the imagined future. ${ }^{\text {ii }}$ Each participant was invited to keep a diary for one month after the interview, to record their reflections on their everyday life, events, and thoughts relating to the interview themes. Participants recorded their mundane and significant reflections, prompted by routine and critical or fateful (Giddens, 1991) moments/events, which enhanced their sense of control over the stories they told (e.g. 
Holliday 1999, 2004). Participants were also asked to complete a mind-map, which was either done immediately after the interview or completed and returned later (Taylor and Snowdon, 2014b).

Most of the participants considered themselves to be white British, with only a few identifying as white Other such as Greek Cypriot (1 interviewee), Spanish (1), and Italian (1). In terms of sex and gender identity 19 participants identified as female, 15 as male, 2 as gender-queer, 1 as gender-queer and transgender, and 1 as transsexual female-to-male. According to self-ascription, the sexual identity of participants can be broadly categorised as gay (15 respondents), lesbian (13), bisexual (5), queer (4), and asexual (1). Most participants self-identified with the denomination of their church: Church of England (6 participants), Methodist (3), Catholic (2), Quaker (2), Charismatic (1), Ecumenical (1), and Evangelical (1). Two participants identified as Unitarian but with Pagan and Buddhist leanings. Where churches were nondenominational, like the Metropolitan Community Church (MCC) (15 participants), some participants also identified with the denomination within which they had been brought up (Church of England, 3 participants; Catholic, 2; Greek Orthodox, 1; and Methodist, 1). Five other participants did not attend a church, attended a nondenominational church (other than MCC), did not know or did not identify with the denomination of their church. ${ }^{\text {iv }}$

For the purposes of this project, young people were broadly defined as under-35 years, with the youngest respondent being 17 and the oldest being 34 years old (the mean age of respondents was 24 years old). In line with comparable youth studies (Kubicek et al., 2009) the first call for LGBT Christians to participate in the project defined young adults as 16 to 24 years of age. However, 'youth' is a contested term and can signify a very wide age range, as apparent in the fieldwork process. The experiences and meanings associated with it are socially constituted, varying both cross-culturally and historically. Valentine et al. (2003: 481) recognise that even when young people leave the family home it 'continues to be the site through which many of their individual biographies and expectations are routed' beyond the tidy age of 24 . By increasing the upper age range of participants to 35 years the complexity in defining 'youth' and the significance of this (expanding) point in the life-course, was acknowledged.

Overall the project recruited a very middle-class sample, typical of sexualities research generally and often seen as symptomatic of 'hard to reach' groups where more advantaged participants are perhaps more likely to come forward (see Taylor, 2007). The majority of respondents did not easily identify in terms of social class as a personal identification, but did use this as a classifying device to describe others, their families, backgrounds, schooling experiences, whilst often still reluctant to attach this to themselves personally (Taylor and Scurry 2011, Falconer and Taylor 2016). Class was ambivalently articulated, and not always explicitly claimed, participants often alluded to it culturally, spatially, and emotionally (not 'fitting in'), if not in economic terms. The class positions of respondents also came through in discussions about tastes, abilities, networks and friendships, including via musical involvement (Taylor et al. 2014), echoing existing research on gendered and classed musical stereotyping and inequalities in young people's participation in music in schools. From the 38 interviewees who participated in the project, 34 had direct experience of university education. At the time of the interviews, 21 participants were currently attending a 
university course, 12 had recently completed a university degree, and 1 was an Alevel student intending to secure a place at university the following year. Six of these 34 participants were either currently studying, or had recently completed, multiple degrees, higher degrees at postgraduate level or $\mathrm{PhD}$ courses.

Classed ideas and expectations emerged in interviewees' accounts of parental expectations and the call to 'be someone' ('No, no, no, they didn't want ... [a] 'useful for nothing'. They preferred me to be a lawyer or a doctor, a medical doctor', Jacob, 30). These preferred routes, of attending a 'good university' (James, 17) were widely communicated across the sample, with Nicola (21) knowing that the aim was to go to university and 'be independent' (see Falconer and Taylor, 2016). Only one interviewee, Kristy (30), spoke of pursuing higher education as unexpected ('In my family you left school and got a job in a shop or factory or something, and you didn't do anything else, you didn't go to University, you didn't do any of those kinds of jobs you needed training for, so nobody really talked about that at home, it was just, you did whatever job you got').

While the interviewee sample was mostly middle-class, the expression of futures was rarely recounted through entitlement logics, with Tom's (20) first desire to not 'end up completely in poverty next year, which is entirely possible' and instead attain a 'solid enough base'. For Nicola, 21, her future was seen as 'a big and scary place' not entirely resolved by the hopeful possibility of achieving a 'beautiful 2:1' degree: 'So that leaves me not very far into the future but I am going to continue to be happy and grow old being happy'. Thus, interviewees' educational expectations and trajectories were both a matter of 'getting on', investing in particular classed futures, but their religious and sexual identities often fractured this as an easy entitlement, becoming a matter of 'getting by'; this speaks to the potential precarity of different middle-class subjects in particular uncertain times. The next section explores such uncertainty as part of the 'times we're in', and as re-orientating youthful selves in compliant and resistant ways.

\section{(Not)Living by Bread Alone: Optimism and (Un)certainty}

Romans Chapter teaches that suffering produces endurance and endurance produces suffering ... 'Worry about nothing, but pray about everything'. It's about being able to ground ourselves in the scripture, all of our hopes and fears, for me as a Christian can be understood and comprehended better through contemplation. Ultimately, we have got God so what more should I really have to want. Jesus Christ teaches that we live by bread alone, that's how our life is. We shouldn't fear too much for worldly things but concentrate on God through Christ. I suppose in some ways you can summarize from all of that that I'm a bit of an optimist - or would strive to be an optimist.

(Andrew, 24)

Neoliberal capitalism shapes contemporary subjectivity where what is 'normal' is driven by a very particular and narrow mode of being, relating and valuing: driven by competition, inequality, and rational self-interest. The conditions of contemporary neo-liberalism arguably demand and shape a future-oriented, enterprising, capital accruing subject (Skeggs, 2004), where capital is accrued in the person, and 
generative of future value (Adkins, 2012). The 'enterprising subject' compelled by competition, inequality and rational self-interest, is a particular kind of middle-class subject who can generate value by accruing capital (Falconer and Taylor, 2016).

Such a mode of being is also governed by a temporality that values reproductive maturity and wealth accumulation, setting up the 'future' as a particular achievement, a realisation of the right 'aspirations' at the right time. Adkins (2009), for example, argues that capitalism is governed by 'clock time' where certain time scales, cycles and life stages are naturalised and internalized. This includes managing and balancing employment and family time, echoed in notions of 'work-life' balance as a neat temporal demarcation, heavily criticized by feminist theorists (Armstrong, 2010). The linking of economic and reproductive worth compels some researchers to ask how might non-normative identities relate to alternative values and temporalities.

Studies of working-class groups highlight differences in 'becoming' otherwise, which are often mis-recognized as deficits, as not arriving in proper familial or vocational positions. Rather than displaying proprietorial orientations towards the future, working-class personhood can be viewed as protectionist rather than proprietorial (Skeggs 1997, Skeggs and Loveday 2012). Living in the here and now, is manifest in a more pragmatic concern for 'getting by' and managing precarity rather than futurity, or 'getting on' (Taylor, 2012; McKenzie, 2015). While class has been a dominant feature in the re-consideration of value, religion and sexuality can further unsettle conceptualisations of value-aspiration among queer religious youth, where a 'calling' might be seen as a form of religious-vocational 'care', mediated too by sexuality.

Within a rather different body of literature from that focusing on classed aspirations either at the structural level of contemporary neo-liberal capitalism or at the more local level of particular classed formations- scholars of gender and sexuality have theorised non-normative gender and sexual identities as subverting normative lifecourse. 'Queer temporality' includes, and arguably extends, beyond gender and sexuality to articulate alternative ways of life, which do not conform to pressures to reproduce, and accumulate wealth. Rarely have these theories been explored empirically (beyond media and textual analysis), and the importance of religion as subversive and generative in this context is under-researched.

Queer theory, in troubling the reification of innate gender categories and the imperative of reproduction, aims to 'articulate an alternative vision of life, love and labour' (Halberstam 2005: 6), a different way of organising human sociality and a different orientation to futurity. Such orientations are not orientated around reproduction or accumulation (Love, 2007) and different 'spacetimes' are explored to think of queer lives in opposition to the institutions of the family and heterosexuality. In the 'clock time' of capitalism (Adkins, 2009) certain time cycles (leisure, recreation, work, family, domesticity), and life stages (growing up, partnering, parenting, careers) are naturalised and internalized reproducing heteronormative 'chrononormativity'. In questioning linear and homogenous time, room is arguably made for the transient, the fleeting, the contingent; for 'strange' temporalities, imaginative life schedules, and even eccentric economic practices (Halberstam, 2005). Such alternative temporalities conjure different futures, where chance or untimeliness are key elements in any political effort to 'bring into existence futures that dislocate themselves from the dominant tendencies and forces of the present' 
(Grosz, 2004: 14). Edelman (2004), and Halberstam (2012) assert that queer subjects should embrace non-productivity and resist narratives of futurity explicitly bound in capitalist accumulation. However, this side-lines practical and pragmatic (im)possibilities, and the likely intersection of alternative and conservative possibilities in the same time and space, as subjects navigate broader social contexts. Specifically 'queer' times, prioritizes and isolates 'queerness' above other locations, such as class (Taylor, 2007, 2012; McDermott, 2011). With this in mind, Renold (2008) argues that the emancipatory potential of such alternative narratives are at risk of being overstated with 'queer subversions' only sustainable from places of power, suggesting limited possibilities for the relatively powerless to subvert.

Conceptualisations of queer times risk reinforcing similar assumptions to those often evident in conceptualisations of religious identities, i.e. that their presumed status as exceptions to the mainstream exempts them from the social structural factors that constrain the lives of everybody else. Even so, religious institutions and practices also structure time, at micro and macro levels, from Weberian 'protestant ethics' and deferred gratification, through to Wilcox's (2009) consideration of religious lesbians and how straight-religious time impacts on them. Mapping religion and sexuality together potentially avoids the prioritization of any one of these differences, focusing instead on situational specifics by which certain elements of one's identity becomes muted, and at another time, becomes heightened.

Many interviewees spoke of the need to be flexible and adaptable to be securely placed in the job-market, to be at-the-ready; while for some this was articulated as a freeing of possibilities ('I am pretty flexible when it comes to the future, I am willing to let it take me where it wants', Julian, 20) others spoke more of this as a compulsory orientation, where 'today is today' and everyday immediacy replaces planning, accumulation and future-thinking:

To be adaptable. The only chance is to be adaptable. I would like to have a bit more quietness and tranquillity and settled plans but how things are right now, be adaptable; be ready for whatever is coming.

Q: What do you see yourself doing in the future?

I've no idea. I try not to think about that or what I will become, all the time worried; today is today. I've been worrying about the future hundreds of hours, what's going to happen with the cuts, what is happening with the job, are they going to keep me here or not; the future is not in my hands any more. (Jacob, 30)

Neoliberal demands contrast with what can be considered value activity in Christian terms, such as, e.g. prayer, contemplations and silence. The peculiarly of neo-liberal challenges and conflicts, whereby life experience is imbued with the expectation of individual empowerment and adaptability but actually characterised by powerlessness in the face of a future that seems pre-determined by external factors, was repeated across accounts of 'getting-on' and 'getting by'.

Some interviewees' aspirations were constructed against 'big business', corporate greed, or against some unspecific notion of capitalism in general, and routine and day- 
to-day work specifically. Helen (20) expressed a desire to have 'enough money to live on' while retaining 'freedom and flexibility' and an ability '...to be spontaneous in life' rather than being 'bogged down'. Likewise, in articulating against the grain options, others described pivotal moments and 'heart' changes in deciding what was important to them in life, re-orientating their future employment expectations. John discusses this below in terms of his sexual orientation facilitating a re-thinking of normative success, graduate trajectories and vocational orientations. There is some ambivalence and hesitation here as John moves between what was once desired, to a conflicting present balancing 'social roles', materiality, and 'feeling better'.

I don't know because part of me just thinks I should just do what I wanted to do before, just get a job in business and trudge along and do the 9 until 6,or maybe doing Law, 8 until 10 sort of thing. My friend has started a graduate job ... and is doing 8 to 8 and works Saturdays and it's a three year graduate training programme, and I consider her very successful because that's what I used to view successful as, very professional, it gives you status, it used to be a safe thing. And then all of a sudden I got really emotional and sort of, after I came out at 16, and reinterpreted what my view of success was, and for me it would be some role that provided me with an outlet to sort of express or help, like it became a very 'heart' decision as a career, and now I would pick something very vocational as opposed to before where I'd just pick something about money really, about status, but now I actually want to pick something that expresses or contributes to something. But I've got this conflicting, because I still would like to have a disposable income...

(John, 21)

Like John, several interviewees situated their commitment to caring professions as important for their own sense of worth and social contribution, at the same time as being financially desirable. This was done by imagining themselves inhabiting the more 'senior positions' (George, 23) in caring professions and by casting caring professions rather widely to include, for example, scientists, solicitors, counsellors, doctors, peacekeepers and ambassadors as those actively 'caring' for and contributing to society. For example, Adrian (29) wanted to run his own charity and hoped 'to be a force for change really'. While imagining himself within the field of science, and pursing a $\mathrm{PhD}$, Lesley (21) also spoke of the appeal to be active in politics, to do research, act as a human rights layer or have a future in ministry. Summarising these he states that, 'I want to change the world, I really do'. Rather than dismissing such ambitions as naïve youthful hopes, it is important to situate these as connecting sexuality and religion, where both these orientations create a space for collective change as desired. Such desires interface aspects of 'getting by' and 'getting on' and are at once alternative and conservative, re-inscribing and stretching normative vocational choices.

Rather than expressing a desire for more senior caring roles, both Kirsty (30) and Thomas (34) felt their futures involved 'social work type stuff' at the interface of queer-religion 'around Christian LGBT type stuff':

I want my spirituality to continue growing and meeting new people and building links with them. And I want to help more with the gay community. 
[Partner] does mentoring for the Albert Kennedy Trust for... It's a charity for teenagers, younger people, who are having problems at school or at home, who are gay, and helping them with issues through mentoring, and had something like that been available to me when I was $15,16,17$, it would have been wonderful. And I can see how much good it's doing and that's something that when I've got a bit more time I really want to be involved with, and I've got a lot I can give and I can speak as a Quaker and a gay man, I've got these two experiences: I've got this experience of what it's like to have had all this prejudice, but I've survived it, and also being someone with faith in an increasingly secularizing world, and just show to people that it's normal.

(Thomas, 34)

It is not necessarily the case that a religious identity includes a critique of capitalism, or any re-situating of value, nonetheless respondents made explicit connections between dissatisfaction with the lack of collective welfare, re-orientations towards these caring logics, and critique of 'clock time', ('...8 until 10 sort of thing...'), and salary/status accumulation ('...to pick something that expresses...'). Interestingly, and perhaps unsurprisingly and also pragmatically based, participants wanted to help the 'weak, needy and poor', rather than being 'weak, needy and poor' themselves. The balance between alternative and normative narratives and choices, involves aligning with recognizable neoliberal identities for themselves whilst concurrently tackling the negative outcomes of neoliberal capitalism for others. Such desires interface aspects of 'getting by' and 'getting on' and are at once alternative and conservative, re-inscribing and stretching normative vocational choices.

\section{Church Futures: Religious Optimism and (Un)Becoming}

Many, if not all, interviewees had considered vocational roles within (various) Churches, as sites of collective care and familial-type identities, whereby Church community was seen - and questioned - as 'family'. These vocational desires were rather queer in themselves, stretching the language and usage of 'vocation' in most mainstream Christian circles, as typically reserved for ordained ministry. Stretched possibilities of 'vocational roles' included a much wider range of responsibilities in church, including 'ministerial roles' (as assumed to include both lay and ordained people) and non-stipendiary service. That these desires exist within marginalised gendered-queer presences within Church 'vocations', and that young participants were framing these as wide and possible is significant (see Taylor and Snowdon, $2014 b$ ). Such considerations are of interest in highlighting the intersection of the vocational and the familial in (queer) re-shapings of 'getting on' and 'getting by'. Many of young participants had religious vocations in mind and were considering their possible future place in these fields, with and against a sense of inclusive practices and possibilities. Many participants considered if, for example, inclusive churches, such as the Metropolitan Community Church (MCC) founded in, by, and for, LGBT community, would represent more pragmatic and comfortable locations, while also being cautious that vocations within somewhat peripheral Churches could render them economically precarious by virtue of being unattached to traditional established Churches.

Nonetheless many respondents frequently expressed future religious vocation as a 
'calling'. The idea of a 'calling', as a specifically religious drive into the future does itself subvert some of the linear logics of educational attainment followed by employability, and the separation of the emotional private self, from a public rational and working self. But such 'callings' were also deflected and silenced in the context of hostile and emotive views regarding the public place of LGBT visibility in religious contexts. For example, Estelle (25) had initially planned a certain kind of religious future, going to university to study Theology but her feelings of disconnect meant that she changed course after just two weeks (see Falconer and Taylor, 2016). Often religious orientations, possibilities and practicalities were in motion and were seen to be sites of future reconciliation, even when definite 'callings' and actualised pursuits of that future (such as in studying Theology) were interrupted and uncertain:

Obviously I'm going to continue pursuing ordination. I think that is really what I want to do and it's obviously what I feel like I'm called to do. It's a very unfashionable term outside the Church to talk about 'calling' but 'vocation' is a much more socially acceptable term. Because a lot of MCC priests are non-stipendiary I will probably consider a chaplaincy career alongside that. I'm looking for a placement in higher education chaplaincy at the moment ... I do worry about not being able to find work, not just in the short term but actually even post ordination, will there be work in the Church for me? Will it be funded? Will I have to move, potentially move countries? But I think despite that I plan to continue working with MCC.

(Kelly, 26)

I'm currently undergoing a process with the local diocese and that is to discern my vocation as I feel drawn to the Priesthood. That's where I see myself heading and so far that is where I feel God is pointing me and really I have understood that sense of calling over a period of two and a half years. So I am on a journey of exploration and growth in order to take me to the next step.

(Andrew, 24)

Such pursuits, situated with a complex matrix of aspiration ('I think that is really what I want to do'), compulsion ('calling') and pragmatics ('Will it be funded?') are not likely to be recognised as 'queer' in academic writings, but nevertheless stretch the go-to parameters in describing LGBT youth trajectories (Yip and Page, 2013; Taylor and Snowdon, 2014a):

I didn't really know till I was 16 , when I got a very strong calling to the priesthood and then from 16 onwards, I always wanted to be a priest. That was a really big factor in my direction of life, and my university. I had no plan to go to university, I was training up to become an organist and I was going on with that and then I sort of stopped it as soon as I got to 16 and focused on becoming a priest ... Obviously the pivotal point in that was my vocation, when I first received news of my vocation, what God wanted me to do. Then it very much intensified and I started reading a lot more and studied my degree in Theology. My vocation to the priesthood, that really changed for me, made 
everything more intense.

(Stephen, 22)

My plans for the near future are to continue coming to the church, to this church, for worship, and to continue studying...I'm looking at doing Theology, so a completely pretty different direction from what I've been doing, but I'd like to, maybe at some point in the future, go and do a course on that. I'm not achieving spiritually what I need to achieve, not being able to give it the dedication and the commitment. That's my biggest fear, my dedication to my spiritual growth.

(Valerie, 28)

Below, both Andrew and Claire express quite a paternalistic and potentially rather patronising version of religious reach and relevance, as 'challenging', 'gritty', and even comedic places are invoked as sites of need, care and investment. Andrew situates such cares locally within a 'return to nature' religious narrative, where investment is seen to reap the most benefits - for himself as a future minister, and a larger disadvantaged community:

... there is a lot to be said for ministries now, there is a lot of ministries growing particularly in more deprived areas which is a lot about reach. There is a TV series on at the moment, called Rev, with Tom Hollander. It's a comedy, but it is a very gritty comedy and that highlights, very accurately I would say, the Church's current role and experience from the perspective of a Parish Priest in a very challenging Parish. But I also have an interest in the environment as well so think there will be particular challenges in a very rural...it actually looks very comfortable and Vicar of Dibley but I can see the challenges there and I can actually see the benefits that you could reap from that, being in a very rural environment looking at how we can preserve God's creation and how we can nurture it, as we were commanded to in the book of Genesis...

(Andrew 24)

Like Andrew, Claire located her religious growth and belonging, alongside a collective community meaning and belonging, yet the language of 'planting a Church' in a rural location arguably conveys potentially troubling links between self-change and community change echoing traditional 'mission' dimensions of religion. That said, Claire is specifically dwelling of the possibility of fostering a Metropolitan Community Church (MCC), in, for and by LGBT groups, potentially stretching 'conservative' dimensions of religion, towards an alternative imagination:

We have talked about moving to - this is going to sound a bit crazy - but moving to $[\mathrm{X}]$ ! Just because it's somewhere that we've found that we really like and we've been talking about how there needs to be more MCC churches in the UK. And we've been wondering, [partner] and I, if we could start a church somewhere, which is a really big thing. But we're just taking it one 
step at a time ... I think everything we've learned from MCC, we can carry to the church. (Claire 24)

Religious hopes intersect aspects of 'getting by', where sexual-religious identities and presences sometimes do not easily sit together, felt as hostility, not belonging and as 'heart changes' compelling (future) reconciliation. Both Andrew and Claire, identify the 'challenges' and 'benefits' of religious investment where, these combine resourced hopes to 'get on', to attain vocational roles within Churches, and to imagine an inclusive elsewhere to be filled with queer religiosity. In turn, the narrative of easily 'getting on' is interrupted by queer precarity and religious uncertainty and by, for example, the routinized practice of dedication, abiding by scripture, spiritual growth and doubt - unhurried practices which arguably slow down the acceleration of neo-liberal times and forward motion of youthful 'becomings'. In current times of 'aspiring', 'post-welfare' or 'crisis' youth transitions, sexual-religious identification mediate the construction of vocational and familial futures, complicating privatepublic divides, where Church may be cast as family and vice versa. Rethinking such public-private intersections, allows a more nuanced negotiation of subversive and conservative futures.

\section{Family Futures: Publics-Privates}

The right to 'family' existence has been a contested and celebrated point in sexualities research, with some scholars noting the 'world we've won' in securing LGBT sexual citizenship, including the right to same-sex marriage in many parts of the world (Weeks, 2007). In some ways this is seen to constitute a freedom and access to the future, withheld from previous LGBT generations. But the (secular) language of 'becoming' and 'citizenship' also centres an older LGBT 'sexual citizen' (as consumer, citizen, resident) and once again 'youth' slip out of this frame, constituting another intersectional gap in thinking about family futures. The 'calling' to religion as a site of present-future vocational investment, highlights pragmatic and caring orientations, as well as deference to an ultimate authority ('... what God wanted me to do...'). These stretches and balances are also played out in respondents' articulations of family futures, as a site of contested, classed, and gendered reproductions (Taylor, 2009; McKenzie 2015).

Participants often highlighted supportive connectivities (Weeks et al., 2001), describing the potential of (religious) vocations and family lives, echoing research on class and gender relations (Mellor, 2010). In different configurations of being, relating and valuing, caring has been seen an essential way in which working-class groups - and particularly working-class mothers - live with others, often outside the norms of respectable heteronormativity (Skeggs, 1997; Taylor, 2009). Orientations towards immediacy rather than futurity can involve efforts to have a good time in bleak conditions, to make the best of limited circumstances, and to rely on 'supportive connectivities' rather than 'self accumulation' (Skeggs, 2011; Hollingworth, 2014). Familial socialities, can also involve the gift of attention over time as a distinct value (Skeggs and Loveday 2012), stretching heteronormative 'spacetimes' (Halberstam, 2005; Love, 2007). 
Here, however, many interviewees did hope for normative lives ('the suburban life'), situated alongside rather than departing from broader social expectations and pressures, so while Julian states that '..I am pretty flexible when it comes to the future, I am willing to let it take me where it wants...', he nonetheless frames this flexibility via certain (homo)normativities:

In my dad's last letter, his main worry has been that being gay has therefore voided my chance of a normal future and that is precisely the opposite of how I feel. I don't know whether it's optimistic to hope this but I have always been hoping for just a normal, have a relationship, maybe adopt a kid, own my own house, have a good job; it's always been fairly normal in my mind, in terms of the future. At the moment, in terms of the here and now, I am trying to work on my dad and trying to get him to see that this is what I want and hopefully that is possible.

(Julian, 20)

While perhaps just a slip, it is interesting to note that Mark describes this contained domesticity '...more as a vague futuristic possibility rather than a concrete plan':

I probably do see myself having a very conventional domestic sort of arrangement with my partner, other than the fact that he'll be a male. I never thought about having children until quite recently actually when there have been moments where I've been watching programmes on TV and there have been moments when I've thought I'd be a good father; moments that get you thinking. I don't know, either sitcoms or drama programmes where such wild ideas of what life is happens, makes you think, 'What would my life be like?'

(Mark, 21)

Within the context of historical non-recognition, and continued social injustice, it is feasible to re-think these everyday familial hopes as alternative (Weeks et al., 2001; Taylor, 2009), in the way that feminist authors have sought to imbue working-class hopes with value. Stephen's account highlights the desirability of 'honesty' as a practice, place, and identity ('a priest that is openly gay') where times and spaces do not collide:

My plan for the future is I hope to get married, I hope to have that union blessed, I hope to become a priest but I hope to become a priest that is openly gay and can be honest about my relationship; it brings me nothing but love and support and I just want to be open about that, really. I don't want to have to lie, or have my boyfriend at the back of the rectory somewhere, only allowed out on week-ends kind of thing. I think that's a real part of what I've been doing with 'Inclusive Church' and everything, is actually honesty.

(Stephen, 22)

In imaging family futures, respondents often made reference to the place of religion in 
their family lives, including, for example, via same-sex marriages and ceremonies ('I would like to do the boring settle down, kids possibly, that sort of settled life. And if the church could be involved in that, then great', Evelyn, 26):

I'd like a house, a car, children, I'd like to be able to provide for my children and I'd like to live forever with my wife. I'd like to be married. I'd like a nice job, I'd like to go on holidays once a year, and I'd like my children to be able to talk to me about anything and it would be nice if they could experience the same sort of religious experience as I have, but I wouldn't be fussed if they didn't. If they turned round to me and said, 'I'm straight and not a Christian' then I'd be like, 'That's fine. Do you love me? Excellent, that's good.'

(Nicola, 21)

Nicola's question seems to echo a central consideration in this article: on the one hand this centralisation of family-child-love may be seen as a particular refraction of the ethos of liberal acceptance, while on the other can be understood as subversive and unsettling and intersecting religious-sexual identities in publics-private spheres, and the forging of pragmatic and aspirant futures.

\section{Conclusion}

Intersectional relations of sexuality and religion actively construct young people's aspirations, towards pragmatic and caring orientations, and away from a selfaccumulating subject able to 'get on' and 'get ahead'. This includes a 'calling' to religion as a site of present-future vocational investment, even as the gendering of these investments - and material realisations - remains a powerful constraint (Taylor and Snowdon, 2014a). Here, religion can be queered as an inclusive practice and one which young LGBT people are not automatically excluded from in their futureorientations and pragmatic aspirations in 'getting-by'. Young people may actively conceive of alternatives to dominant exchange value relationships and structures of chrono-normative temporalities, as upwardly mobile, aspirant and becoming. Here, both a sense of queer precarity - of not necessarily having access to the 'right kind' of normative futures - as well as a sense of religious (un)certainty - of religious commitment potentially in doubt - mediated young people's becoming otherwise.

Intersectional relations of both sexuality and religion construct young people's aspirations, pragmatic and caring orientations, including a calling to religion as a site of present-future vocational and familial investment. Religion and sexuality constitute significant fields of existence potentially challenging, resisting and responding to heteronormative neoliberal capitalist forms of selfhood and futurity, interfacing 'getting by' and 'getting on' in vocational and familial choices. Queer theorisations on alternative values centre 'strange' temporalities and futurities: ways of relating to people that are not orientated around exchange and accumulation and imaginative uses of time which are not oriented around reproduction or productivity (Halberstam 2005). This represents a useful shattering of chrono-normative and 'clock time' logic (Adkins, 2009) but it is also necessary to take account of the material contexts of such stretches and subversions. Overall, the article hopes to contribute to theorising the intersection of sexuality and religion, and to further understanding of the subversive potential of alternative values and 'futures'. This contribution may also work against 
the disciplinary division witnessed in the separation of 'youth studies', 'sexuality studies' and 'religious studies'.

\section{Bibliography}

Adkins, L. (2009) 'Sociological Futures: From Clock Time to Event Time', Sociological Research Online, 14 1-5

Adkins, L. (2012) 'Out of work or out of time? Rethinking labor after the financial crisis', South Atlantic Quarterly, 111 621-641

Armstrong, J. (2010) 'Class and Gender at the Intersection, Working-Class Womens' Dispositions Towards Employment and Motherhood' in Taylor, Y. (ed. 2010) Classed Intersections: Spaces, Selves, Knowledges Ashgate.

Allen, K. and Taylor, Y. (2013) 'Failed femininities and troubled mothers: gender and the riots' Studies in the Maternal Special Issue on Austerity Parenting Volume 4 Issue 2 .

Browne, Katherine and Nash, C.J. (eds) (2010) Queer methods and methodologies: intersecting queer theories and social science research

Edelman, L. (2004) No Future: Queer Theory and the Death Drive. New York: Duke University Press

Evans, S. (2010) 'Becoming 'Somebody': Examining Class and Gender Through Higher Education’ in Taylor, Y. (ed. 2010) Classed Intersections: Spaces, Selves, Knowledges Farnham: Ashgate.

Taylor, Y. and Falconer, E. (2016) 'Negotiating Queer and Religious Identities in Higher Education: Queering 'Progression' in the 'University Experience' British Journal of the Sociology of Education

Friedman, S. (2015) Comedy and Distinction. London: Routledge

Giddens, A. (1991). Modernity and self-identity: Self and society in the late modern age. Stanford: Stanford University Press.

Gross, M., \& Yip, A. K. (2010). Living spirituality and sexuality: A comparison of lesbian, gay and bisexual Christians in France and Britain. Social Compass,57(1), 4059.

Grosz, E. (2004) The Nick of Time. New York: Duke University Press

Guest, Mathew, Elizabeth Olson and John Wolffe (2012) "Christianity: Loss of Monopoly", in Woodhead and Catto (eds) Religion and Change in Modern Britain, London: Routledge. )

Halberstam, J. (2005) In a Queer Time and Place. New York: NYU Press 
Heaphy, B. (2007) Late Modernity and Social Change: Reconstructing Social and Personal Life. London: Routledge.

Heelas, P. and Woodhead, L. (2005) The Spiritual Revolution: Why Religion is Giving Way to Spirituality. Oxford: Blackwell

Love, H. (2007) Feeling Backward: Loss and the Politics of Queer History. Harvard University Press

Maddox, Marion (2013) "'Rise Up Warrior Princess Daughters": Is evangelical women's submission a mere fairytale?' Journal of Feminist Studies in Religion 29(1) 7-23.)

McDermott, E. (2011) 'The world some have won: sexuality, class and inequality In Taylor, Y. (ed) Special Issue 'Sexuality and Class', (2011) Sexualities 14(1) 63-78

Mckenzie L. (2015) Getting By: Estates, Class and Culture in Austerity Britain. Published by Policy Press.

Mellor, J. (2010) 'The Significance of Bonding Capital: Class, Ethnicity, Faith and British Muslim Women's Routes to University’ pp. 73-93 in Taylor, Y. (ed. 2010) Classed Intersections: Spaces, Selves, Knowledges Farnham: Ashgate.

Modood, T. (2015) 'State-Religion Connections and Multicultural Citizenship' in J. L. Cohen and C. Laborde (eds) Religion, Secularism, and Constitutional Democracy, Columbia University Press.

Rasmussen, M.L. (2010) 'Secularism, religion and 'progressive' sex education' Sexualities, 13(6): 699-712

Renold, E. 2008. Queering masculinity: Re-theorising contemporary tomboyism in the schizoid space of innocent/heterosexualized young femininities. Girlhood Studies 1(2):129-151.

Rivers, I., \& D'Augelli, A.R. (2001). The victimization of lesbian, gay, and bisexual youths: Implications for intervention. In A.R. D’Augelli \& C.J. Patterson (Eds.), Lesbian, gay, and bisexual identities and youth: Psychological perspectives (pp. 199223). New York: Oxford University Press.

Skeggs, B. (1997) Formations of class and gender London: Sage

Skeggs, B. (2004) Class, self, culture London: Routledge

Skeggs, Bev and Loveday, Vik. 2012. 'Struggles for value: value practices, injustice, judgment, affect and the idea of class. British Journal of Sociology, 63(3), pp. 472-49

Taylor, Y. (2007) Working-class lesbian life: Classed Outsiders. (Palgrave). 
Taylor, Y. (2009) Lesbian and Gay Parenting: Securing Social and Educational

Capital Palgrave Macmillan

Taylor, Y., Hines, S. and Casey, M. (eds) (2010) Theorizing Intersectionality and Sexuality. Palgrave

Taylor, Y. (2011) 'Queer Presences and Absences: Citizenship, Community, Diversity - or Death' Feminist Theory 12(3): 335-341

Taylor, Y. and Scurry, T. (2011) 'International and Widening Participation Students' Experience of Higher Education, UK’ European Societies 13(4): 583-606

Taylor, Y. (2012) Fitting into place? Class and Gender Geographies and Temporalities. Ashgate

Taylor. Y, Falconer, E. and Snowdon, R.( 2014) 'Queer Youth, Facebook, and Faith: Facebook Methodologies and Online Identities' New Media and Society

Taylor, Y. and Snowdon, R. (eds) (2014a) Queering Religion, Religious Queers Routledge

Taylor, Y. and Snowdon, R. (2014b) 'Making Space for Young Lesbians in Church?' Journal of Lesbian Studies 18(4): 393-414

Taylor, Y. (2015) Making Space for Queer Identifying Youth. Palgrave Pivot

Valentine, G., Skelton, T., and Butler, R. (2003) 'Coming out and outcomes: negotiating lesbian and gay identities with, and in, the family'. Environment and Planning D: Society \& Space 21(4): 479-499.

Weeks, J., Heaphy, B. and Donovan, C. (2001) Same-Sex Intimacies. Routledge: London

Wilcox, M. M. (2009) Queer Women and Religious Individualism. Bloomington, Indiana University Press.

YIP, A.K.T. (1997) Dare to differ: Lesbian and gay Catholics' assessment of official Catholic positions on sexuality Sociology of Religion. 58(2), 165-180

Yip, A. K. T. and Page, S. (2013) Religious and Sexual Identities: A Multi-faith Exploration of Young Adults, Farnham: Ashgate.

\footnotetext{
${ }^{\mathrm{i}}$ Interrogating the distinction between inclusive/traditional churches is beyond the scope of this article, while it is recognised that patterns of inclusivity among churches do not fall simply along traditional/ progressive lines. For example, many churches that are most popular with young adults and in inner-cities are highly progressive in their use of technology, style of worship and approach to community building, and yet affirm highly conservative perspectives on moral issues, especially to do with gender and sexuality. It is difficult to make sense of churches' response to sexual identities using a single spectrum. For an influential model of how progressive and conservative occupy the same space within churches, see Maddox (2013).
} 
ii The definition of 'Christian' and indeed 'religious' is contested - and often especially so for youth people generally and queer youth in particular (Yip and Page, 2011; Taylor and Snowdon, 2014a). Various Christian denominations have articulated different perspectives that are enormously complicated and contrary (Gross and Yip 2010). The diversity within Christian organisations and practices as well as between Christina individuals is acknowledged, while this paper focuses on commonalities amongst the sample. Most participants identified with the denomination of their church: Church of England (6 participants), Methodist (3), Catholic (2), Quaker (2), Charismatic (1), Ecumenical (1), and Evangelical (1). Two participants identified as Unitarian but with Pagan and Buddhist leanings. Where churches were non-denominational, like the Metropolitan Community Church (MCC) (15 participants), some participants also identified with the denomination within which they had been brought up (Church of England, 3 participants; Catholic, 2; Greek Orthodox, 1; and Methodist, 1). A substantial body of work on the LGBT population entirely disregards any religious aspect of LGBT lives or refers to such (dis)associations as negative, harmful or superficial (Jordan, 2011; Gross and Yip, 2010; Kubicek et al., 2009; Yip, 1997). Whilst non-heterosexuality is still often associated with secularism, this study works against this dominant discourse by exploring the experiences of young LGBT people's connections with Christianity. Rather than assume that sexuality and religion - in this case Christianity - are separate and divergent paths, the ESRC 'Making Space for Queer Religious Youth' project explores how they might mutually and complexly construct one another (Taylor and Snowdon, 2014a, 2014b). There is considerable variety within the category of 'Christianity' and it is the 'queer' stretching, fitting ('sounding' and 'feeling') which the broader research project highlights, also questioning the binary of (non)traditional approaches and backwards versus progressive stances towards religion and sexuality.

iii The interviews were then transcribed and coded in Atlas.ti and we used approximately 50 codes based on an analysis of the transcripts to draw out common themes discussed by participants.

iv The summary of demographics and methodologies is necessarily brief here, please see Making Space for Queer Religious Youth, for a fuller discussion on how were the interviewees recruited (also see Guest et al., 2012). 